\title{
Contamination by trace metals and their trophic transfer to the biota in a Mediterranean coastal system affected by gull guano
}

\author{
Geraldina Signa*, Cecilia Doriana Tramati, Salvatrice Vizzini \\ Department of Earth and Marine Sciences, University of Palermo, CoNISMa, via Archirafi 18, 90123, Palermo, Italy
}

\begin{abstract}
Transitional environments are vulnerable interface systems, ecologically connected with adjacent systems by several biotic or abiotic flows. The coastal system of the Marinello ponds (Tyrrhenian Sea, Italy) is affected by a colony of yellow-legged gulls Larus michahellis (Naumann, 1840), resident on the cliff beside the ponds. To investigate the role of the gull colony as a potential source of allochthonous non-essential trace metals (As, Cd, Pb and total mercury, THg) and the consequent metal trophic transfer to the biota in the ponds, we collected guano, surface sediment and biota from 3 ponds with different levels of avian input. The highest concentrations were observed in guano and surface sediment of the seabird-influenced pond, suggesting that trace metals have undergone biotransport mediated by seabirds. To test for biomagnification, the trophic pathways of the ponds were first identified by $\delta^{13} \mathrm{C}$ and $\delta^{15} \mathrm{~N}$, revealing the existence of important differences in accordance with the importance of guano input. Trophic transfer along the food chains was metal-specific. Only THg was found to biomagnify based on significant positive linear regression of $\log \mathrm{THg}$ versus $\delta^{15} \mathrm{~N}$ in organisms. In contrast, As, Cd and Pd significantly biodiluted through the food chains. Regression line slopes were homogeneous among ponds, suggesting that metal transfer along food chains occurs independently of the background contamination levels. Our findings provide new insights about the role of seabirds in contaminant dynamics in transitional environments in light of the high abundance of seabirds and the current lack of knowledge about seabird-mediated ecological processes in the Mediterranean area.
\end{abstract}

KEY WORDS: Contaminants · Biomagnification · Seabird · Yellow-legged gull · Allochthonous input $\cdot$ Stable isotope $\cdot$ Mediterranean lagoon

\section{INTRODUCTION}

Transitional waters are complex coastal environments characterised by hydrological and geochemical constraints, which make them highly heterogeneous systems. Shallow depth, limited size, confined circulation and weak hydrodynamics associated with ecological connectivity with adjacent systems also make these environments unstable and sensitive to natural and anthropogenic pressures. Ecological connectivity triggers exchanges of biota and organic and inorganic materials, frequently resulting in the accumulation of allochthonous organic matter and pollutants and possibly in alterations of the natural equilibrium (MarínGuirao et al. 2005, Boubonari et al. 2009). Of all pollutants, metals are among the most ubiquitous and increasingly reach coastal ecosystems from both point sources (e.g. industries, sewage, outfalls; Bellucci et al. 2002, Marín-Guirao et al. 2008) and diffuse sources (e.g. atmospheric deposition, agricultural drainage; e.g. Migon et al. 1991, Green-Ruiz \& Páez-Osuna 2001). Once trace metals reach aquatic systems, their behaviour is highly dynamic: they can be adsorbed to suspended particles with subsequent sedimentation 
(Turner 2002), and then can be remobilized in the water column and accumulated in aquatic organisms (Eggleton \& Thomas 2004, Du Laing et al. 2009). Furthermore, the progressive accumulation of trace metals with increasing trophic level, i.e. biomagnification, can occur (e.g. Barwick \& Maher 2003, Croteau et al. 2005, Ikemoto et al. 2008). While the effect of abiotic drivers (e.g. tides, currents) in redistributing pollutants across coastal boundaries is well studied (e.g. Knee \& Paytan 2011, Acquavita et al. 2012), the role of biotic vectors is overlooked.

Among the faunal groups inhabiting coastal areas, seabirds are a most important component in moving and redistributing materials across coastal boundaries affecting ecosystem functionality (Burger \& Gochfeld 2004), representing a well-documented biological transport pathway from ocean to land (e.g. Blais et al. 2005, Brimble et al. 2009) and vice versa (e.g. Hahn et al. 2007, Signa et al. 2012). A number of ecological characteristics, such as their high trophic level, gregarious behaviour, widespread distribution and often their reliance on rubbish as a food source (Burger \& Gochfeld 2004, Ramos et al. 2009), make seabirds potential bioindicators of coastal and marine pollution (Furness \& Camphuysen 1997, Burger \& Gochfeld 2004). For instance, in Arctic systems, seabirds channel various subsidies (guano, feathers, carcasses, dropped food) to the areas surrounding nests, creating localized 'hotspots' of contamination (e.g. Blais et al. 2005, Choy et al. 2010a,b, Michelutti et al. 2010). In contrast, information about the effect of bird-mediated transport in Mediterranean coastal area is lacking, despite the widespread seabird distribution.

The Marinello ponds constitute a very recent and dynamic coastal system in the southern Tyrrhenian Sea (Mediterranean Sea, Italy; Fig. 1). Signa et al. (2012) recently reported on the influence of a small gull colony, resident in the adjacent cliff, on trophic status and productivity of the ponds. In the present paper, we investigated the role of the Marinello gull colony as a potential source of allochthonous contaminants by assessing contamination with the nonessential trace metals arsenic (As), cadmium (Cd), lead $(\mathrm{Pb})$ and total mercury $(\mathrm{THg})$ in guano and surface sediments of 3 selected ponds. We then evaluated the occurrence of ornithogenic trace metal trophic transfer to the biota, and whether such transfer is connected with the differing background trace metal contamination.

In order to evaluate the occurrence of metal trophic transfer, trophic pathways were first characterised using carbon and nitrogen stable isotopes $\left(\delta^{13} \mathrm{C}\right.$ and

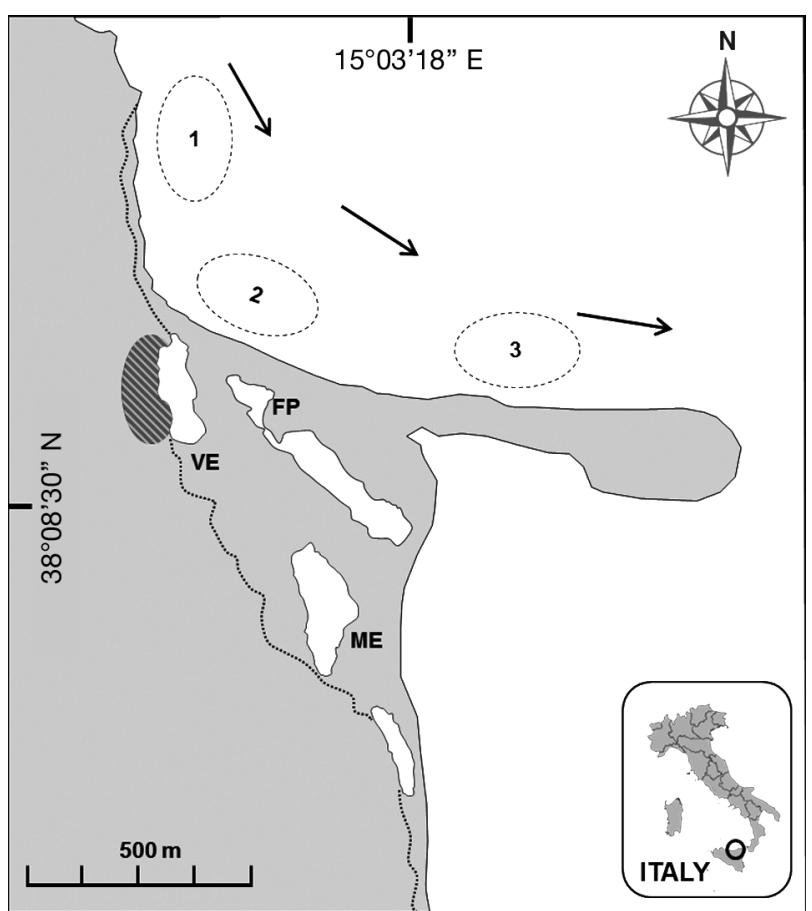

Fig. 1. Study area showing sampling sites. Pond sites: Verde (VE), Fondo Porto (FP), Mergolo (ME); coastal sites: 1, 2, 3. Dotted line: edge of the promontory of Tindari. Gray striped oval: site of the yellow-legged gull colony on the Tindari cliff. Arrows: direction of the prevailing currents

$\delta^{15} \mathrm{~N}$ ), because of their robustness and efficacy as a tool for tracing organic matter pathways and trophic relationships in complex ecosystems (e.g. Magni et al. 2008, Carlier et al. 2009). Further, the correlations between $\delta^{15} \mathrm{~N}$, used as a proxy of trophic levels (Post 2002), and contaminant concentrations in food web components allowed the estimation of contaminant trophic transfer, as recently widely used (e.g. Corsolini et al. 2007, Ikemoto et al. 2008, Marín-Guirao et al. 2008).

\section{MATERIALS AND METHODS}

\section{Study area}

The Marinello ponds are located in the Gulf of Patti on the north-eastern coast of Sicily (Italy, Tyrrhenian Sea, Mediterranean; Fig. 1). Together with the overlying promontory of Tindari, the coastal system constitutes a Nature Reserve and a Site of Community Importance (code ITA030012). At the beginning of the 19th century, the particular hydrogeomorphological features of the whole area determined the forma- 
tion of littoral bars, at present delimiting 5 small coastal ponds (Verde, Fondo Porto, Porto Vecchio, Mergolo and Marinello). Completely lacking freshwater discharge, the innermost ponds are mainly influenced by surface run-off from the surrounding lands while the outermost ponds are influenced by seawater inflows through infiltration or high waves during storms (Mazzola et al. 2010). Of these 5 ponds, 1 is directly affected by the presence of a small resident colony of yellow-legged gulls Larus michahellis (Naumann, 1840) on the Tindari cliff beside the pond. Gulls vary in number from 80 to 125 ind. during the year (Signa et al. 2012). They have a mixed diet relying on anthropogenic rubbish as a principal food source (Signa et al. 2012). Three ponds were sampled in this study: Verde (VE), Fondo Porto (FP) and Mergolo (ME), selected according to their increasing distance from the gull colony. The selected ponds are small and shallow, but, while VE is directly subjected to gull guano input, the adjacent ponds, FP and ME, are 200 and $600 \mathrm{~m}$ from the colony. To test the possible influence of the adjacent marine area on pond contamination, 3 coastal sites (distance from the coast: $15 \mathrm{~m}$; mean depth: $3.5 \mathrm{~m}$ ) were also selected along the direction of the prevailing currents (the coastal SE wind-induced currents and the eastward modified Atlantic water (MAW); Millot 1999): site 2 is adjacent to the coastal ponds, sites 1 and 3 are upstream and downstream, respectively (Fig. 1).

\section{Field activities}

Sampling was carried out in May 2009. Gull guano was carefully scraped from the shores of VE. PVC cores (inner diameter: $4 \mathrm{~cm}$ ) were used to collect surface sediment from each pond and coastal site (Fig. 1). We took replicates for sediment characteristics (organic matter: OM, and carbonate content), trace metal and stable isotope analysis, and 3 additional replicates for grain size analysis. Surface water (3 replicates) and the main biotic items were also sampled from each pond. The most abundant macrophytes were collected by hand. The macroalga Chaetomorpha linum and the seagrasses Cymodocea nodosa and Ruppia cirrhosa were found and sampled in all ponds, while the macroalga Caulerpa racemosa was found and sampled only in FP. Shrimps and fish were sampled using a small hand-towed trawl net (length: $3.5 \mathrm{~m}$; mesh size: $3 \mathrm{~mm}$ ). The decapod shrimp Palaemon adspersus and the fishes Atherina boyeri, Gambusia holbrooki and Salaria pavo were common to all ponds, while the fishes Buenia affinis,
Gobius niger, Liza aurata and Syngnathus abaster were found in only 1 or 2 ponds. Three samples of sediment were taken using a $294 \mathrm{~cm}^{2}$ (2000 ml) Van Veen grab (penetration depth $\sim 15 \mathrm{~cm}$ ) from each pond and were wet sieved on the shore through a mesh size of $0.5 \mathrm{~mm}$ for benthic macrofauna analysis. All samples were kept cool and dark upon arrival at the laboratory.

\section{Laboratory activities}

In the laboratory, gull guano was wet sieved through a $1000 \mu \mathrm{m}$ net to remove coarse residuals. The first centimetre of sediment cores was sliced and subsampled for $\mathrm{OM}$ and carbonate content and for trace metal and stable isotope analysis, while for grain size analysis, the bulk sediment was analysed. OM and carbonate content of sediment (wet sieved at $1000 \mu \mathrm{m}$ ) was estimated according to the loss on ignition (LOI) method (Heiri et al. 2001) based on sequential weightings of samples before and after heating at 105,550 and $950^{\circ} \mathrm{C}$. Pre-treatment of bulk sediment for grain size analysis was carried out with hydrogen peroxide and Na-hexametaphosphate to eliminate organic matter and avoid particle flocculation. The whole mixture was then wet sieved through a $63 \mu \mathrm{m}$ net, while the remaining fraction was electromechanically sieved through a DIN ISO 3310-1 standard sieve set to obtain a grain size series with intervals of $1 / 2 \Phi(\Phi=$ $-\log 2 \varnothing \mathrm{mm})$. Before stable isotope analysis, surface sediment was wet sieved at $63 \mu \mathrm{m}$ to get the bioavailable fraction of sedimentary organic matter (SOM) and acidified ( $\mathrm{HCl}, 2 \mathrm{~N}$ ) to remove carbonates. In contrast, $1000 \mu \mathrm{m}$ mesh was selected for trace metals so as to eliminate coarser grains that could interfere with the analysis, and, at the same time, to obtain enough material. To obtain the particulate organic matter (POM) fraction, surface water was filtered through a $200 \mu \mathrm{m}$ mesh net and then onto Millipore cellulose ester membrane filters and precombusted $\left(450^{\circ} \mathrm{C}, 4 \mathrm{~h}\right)$ Whatman GF/F filters for trace metal and stable isotope analysis, respectively. Filters for carbon stable isotope analysis were acidified $(\mathrm{HCl}, 2 \mathrm{~N})$ to remove carbonates. Macroalgae and seagrasses were rinsed with distilled water, and epiphytes were removed by surface scraping. Invertebrates were sorted from sediment and identified to the lowest possible taxonomic level (family, genus or species) under a stereomicroscope (10 to $40 \times$ ). Shell, operculum and exoskeleton were removed from molluscs and crus- 
taceans to extract the flesh. Fish were identified to species level, and dorsal muscle was processed for analysis. All samples were oven dried $\left(40\right.$ and $60^{\circ} \mathrm{C}$ for trace metal and stable isotope analysis, respectively) and ground to a fine powder using mortar and pestle. Trace metal and stable isotope analyses were carried out in triplicate.

Trace metals analysed were $\mathrm{As}, \mathrm{Cd}, \mathrm{Pb}$ and $\mathrm{THg}$. Guano, POM, primary producers and consumers were mineralized in Teflon digestion vessels with $\mathrm{HNO}_{3}, \mathrm{H}_{2} \mathrm{O}_{2}$ and MilliQ deionized water, while sediment was mineralized with $\mathrm{HNO}_{3}, \mathrm{HF}, \mathrm{H}_{2} \mathrm{O}_{2}$, and MilliQ deionized water. The analytical procedure was checked using standard reference materials (recovery comprised between 90 and 98\%): dogfish muscle DORM-2 for consumers, Lagarosiphon major BCR-060 for POM and primary producers and marine sediment MESS-3 for sediment. An inductively coupled plasma optical emission spectrometer (ICPOES, Varian Vista MPX) was used to analyse digested samples. Concentrations of As and THg were also determined using a hydride generation system (VGA-77) linked to the ICP-OES.

Stable carbon and nitrogen isotope ratios of POM, SOM, guano, main primary producers and consumers were analysed in an Isotope Ratio Mass Spectrometer (Thermo Scientific Delta Plus XP) connected to an Elemental Analyser (Thermo Scientific Flash EA 1112). Isotopic values were expressed in conventional $\delta$ unit notation as parts per mil deviations from the international standards, Vienna Pee Dee Belemnite and atmospheric nitrogen $\left(\mathrm{N}_{2}\right)$, following the formula $\delta X=\left[\left(\mathrm{R}_{\text {sample }} / \mathrm{R}_{\text {standard }}\right)-1\right] \times 10^{3}$, where $X$ is ${ }^{13} \mathrm{C}$ or ${ }^{15} \mathrm{~N}$ and $\mathrm{R}$ is the corresponding ${ }^{13} \mathrm{C} /{ }^{12} \mathrm{C}$ or ${ }^{15} \mathrm{~N} /{ }^{14} \mathrm{~N}$ ratio. Analytical precision based on the standard deviation of replicates of internal standards was $0.2 \%$.

\section{Data elaboration and statistical analysis}

Statistical analysis was performed using the software packages Statistica 8.0 and Primer 6.0. Relationships between sediment trace metal concentrations and sediment characteristics (grain size, OM and carbonates) were analysed by general non-linear models. One-way analysis of variance (ANOVA) was carried out to test for differences in sediment characteristics between sites. Cochran's $C$-test was done prior to analyses to test homogeneity of variances. Variances were heterogeneous, thus ANOVA was performed on untransformed data, as it is a robust test even with datasets with heterogeneous variances (Underwood 1997). This is particularly true with a balanced design, as in this study. Results were interpreted using a more conservative significance level $(\alpha=0.01)$ to reduce the possibility of a Type I error (Underwood 1997).

Due to the highly significant differences found in carbonate content between sites (Table 1), geochemical normalization of sediment trace metal data to carbonate content (Horowitz 1985) was carried out to compensate for both the sedimentary granulometric and mineralogical variability of samples. Indeed, carbonate content is an important factor in influencing sedimentary chemical partitioning (Horowitz 1985), as confirmed by the goodness of the quadratic correlations with $\mathrm{Cd}$ and $\mathrm{Pb}\left(\mathrm{R}^{2}=0.66\right.$ and 0.65 , respectively). Normalized trace metal concentration data were used to compare sampling sites by multivariate principal coordinates analysis (PCO) and permutational analysis of variance (PERMANOVA). Once the main trophic pathways in each pond were identified by means of carbon and nitrogen stable isotopes, the species that were not members of these pathways were no longer consid-

Table 1. (a) Textural and geochemical properties (means \pm SD) of surface sediments from the sampling sites. Pond sites: Verde (VE), Fondo Porto (FP), Mergolo (ME); coastal sites: 1, 2, 3. OM: organic matter. (b) 1-way analysis of variance (ANOVA)

\begin{tabular}{|c|c|c|c|c|c|}
\hline (a) Properties & Mud (\%) & Sand (\%) & Gravel (\%) & OM (\%) & Carbonates (\%) \\
\hline VE & $48.41 \pm 12.99$ & $33.32 \pm 1.13$ & $18.27 \pm 4.12$ & $12.23 \pm 1.50$ & $12.83 \pm 0.76$ \\
\hline FP & $1.26 \pm 0.52$ & $97.48 \pm 0.04$ & $1.26 \pm 0.56$ & $1.91 \pm 0.53$ & $1.61 \pm 0.22$ \\
\hline $\mathrm{ME}$ & $33.67 \pm 2.01$ & $56.16 \pm 1.47$ & $10.18 \pm 3.47$ & $5.93 \pm 0.42$ & $34.20 \pm 0.28$ \\
\hline 1 & $0.06 \pm 0.03$ & $62.53 \pm 13.40$ & $37.40 \pm 13.39$ & $2.46 \pm 1.07$ & $3.79 \pm 2.34$ \\
\hline 2 & $0.13 \pm 0.10$ & $81.15 \pm 9.09$ & $18.73 \pm 9.10$ & $2.63 \pm 2.30$ & $4.60 \pm 5.30$ \\
\hline 3 & $5.30 \pm 1.60$ & $53.46 \pm 11.17$ & $41.24 \pm 17.77$ & $2.35 \pm 0.60$ & $1.80 \pm 0.26$ \\
\hline (b) 1-way ANOVA & MS & MS & MS & MS & MS \\
\hline $\mathrm{df}=5$ & $\begin{array}{c}2610.42 \quad 136.04 \\
p<0.001\end{array}$ & $\begin{array}{c}2983.28 \quad 13.13 \\
p<0.001\end{array}$ & $\begin{array}{c}1133.62 \quad 5.36 \\
p<0.001\end{array}$ & $\begin{array}{c}110.69159 .04 \\
p<0.001\end{array}$ & $\begin{array}{c}1003.24 \quad 1358.09 \\
p<0.001\end{array}$ \\
\hline
\end{tabular}


ered, while the more important and abundant species characterising these pathways were analysed for trace metal trophic transfer along food chains. To do this, trace metal data in selected biotic samples were log-transformed, and simple linear regressions were performed using $\delta^{15} \mathrm{~N}$ as the independent variable and the logarithm of trace metal content as the dependent variable. Violation of linear regression assumptions and robustness of the model were tested by analysis of residuals. Homogeneity of slopes analysis was carried out to test whether the covariate $\delta^{15} \mathrm{~N}$ and the factor 'pond' interacted in influencing the log-metal concentrations.

\section{RESULTS}

\section{Sedimentary characteristics and trace metal content}

The most important textural and geochemical properties of surface sediment were significantly different between sites (Table 1). Sediment texture was largely sandy in FP and mixed in VE and ME (sandy silt and silty sand, respectively). Coastal site sediments were also mixed, but mainly constituted by gravelly sand with negligible mud content $(<6 \%)$. Overall OM content followed the same trend recorded for mud, exhibiting the lowest values in FP and the highest in VE. Indeed, OM content was positively correlated with mud $\left(\mathrm{R}^{2}=0.91 ; \mathrm{p}<0.001\right)$ and negatively correlated with sand $\left(R^{2}=-0.68 ; p<\right.$ 0.001). Quadratic regression models were considered most appropriate to describe relationships between sediment characteristics and trace metal concentrations, and only carbonate content and $\mathrm{Cd}$ and $\mathrm{Pb}$ concentrations resulted in a good fit $\left(\mathrm{R}^{2}>0.5\right)$

Content (all means $\pm \mathrm{SD}$ ) of As in gull guano was quite variable $\left(10.71 \pm 4.02 \mathrm{mg} \mathrm{kg}^{-1}\right)$, while $\mathrm{Cd}, \mathrm{Pb}$ and $\mathrm{THg}$ showed less variability $(0.49 \pm 0.14,6.19 \pm$ 0.92 and $1.17 \pm 0.29 \mathrm{mg} \mathrm{kg}^{-1}$, respectively). Normalized trace metal concentrations in sediment showed marked differences among sites (Fig. 2). Higher trace metal concentrations were recorded overall in VE, followed by FP and the other sampling sites, except for THg, which also exhibited high concentrations in ME. At a multivariate level, PERMANOVA on normalized trace metal data confirmed these results $(\mathrm{df}=5 ; \mathrm{MS}=533.62 ; \mathrm{p}<0.001)$, and pairwise tests showed significant differences $(p<0.001)$ among all sites, except between FP and coastal sites 2 and $3(t=$ 0.54 and 0.23 , respectively; $p>0.05$ for both) and between coastal site 2 and both sites 1 and $3(t=1.15$ and $0.63 ; \mathrm{p}>0.05$ for both). PCO revealed a profound difference between VE and the other sites: VE was clearly distinct from the other sites, clustering in the right half of the graph, FP and coastal sites were grouped in the centre, and ME was concentrated on the left (Fig. 3).

Analysis of biota revealed higher concentrations overall of $\mathrm{As}, \mathrm{Cd}$ and $\mathrm{Pb}$ in $\mathrm{OM}$ sources than in consumers, while THg did not follow the same trend (Table 2). Although marked variability was recorded, OM sources exhibited higher concentrations in VE, while this trend was not evident in invertebrates and fish. Among OM sources, POM from VE showed the highest concentrations of $\mathrm{Cd}, \mathrm{Pb}$ and $\mathrm{THg}$, while the highest concentration of As was recorded in the macroalga Chaetomorpha linum from VE (Table 2). Seagrasses also showed a high trace metal bioaccumulation capacity, exhibiting high As and THg content for Cymodocea nodosa respectively from FP and $\mathrm{VE}$, and high As and Pb content for Ruppia cirrhosa from FP and ME. Among invertebrates, the gastropod Cerithium sp. from FP showed the highest concentrations of $\mathrm{As}, \mathrm{Cd}$ and $\mathrm{Pb}$, while the highest $\mathrm{THg}$ concentrations were detected in the isopod Sphaeroma serratum from $\mathrm{VE}$ and in the amphipod Corophium sp. from FP (Table 2). Finally, among fish, the highest concentrations of all trace metals were found in the mugilid Liza aurata from VE. High concentrations of $\mathrm{Cd}$ were also detected in the same species from ME, while Gambusia holbrooki from VE exhibited high levels of both $\mathrm{Cd}$ and As (Table 2).

\section{Stable isotopes}

The $\delta^{13} \mathrm{C}$ range of OM sources was different among ponds, being wider in VE than in ME and FP $\left(\Delta^{13} \mathrm{C}=\right.$ $-19.6,-15.3$ and $-11.9 \%$, respectively; Fig. 4). Not considering the macroalga Chaetomorpha linum, which showed very high spatial variability between ponds in its carbon isotopic signature, OM sources overall exhibited the most depleted values in POM, followed by SOM, macroalgae and seagrasses. Consumers from all ponds fell into the OM range, but consumer ranges were markedly wider in ME and VE $\left(\Delta^{13} \mathrm{C}:-10.5\right.$ and $-9.4 \%$ o than in FP $\left(\Delta^{13} \mathrm{C}:-3.7 \%\right)$. Unlike $\delta^{13} \mathrm{C}$, the $\delta^{15} \mathrm{~N}$ range of OM sources was similar among ponds $\left(\Delta^{15} \mathrm{~N}: 3.0,4.0\right.$ and $2.6 \%$, respectively, for VE, FP and ME), but a trend in ${ }^{15} \mathrm{~N}$ enrichment, both in $\mathrm{OM}$ sources and consumers, was evident from ME to FP and VE (Fig. 4). Linear regression analysis revealed highly significant correlations between $\delta^{15} \mathrm{~N}$ and the log-transformed trace metal 

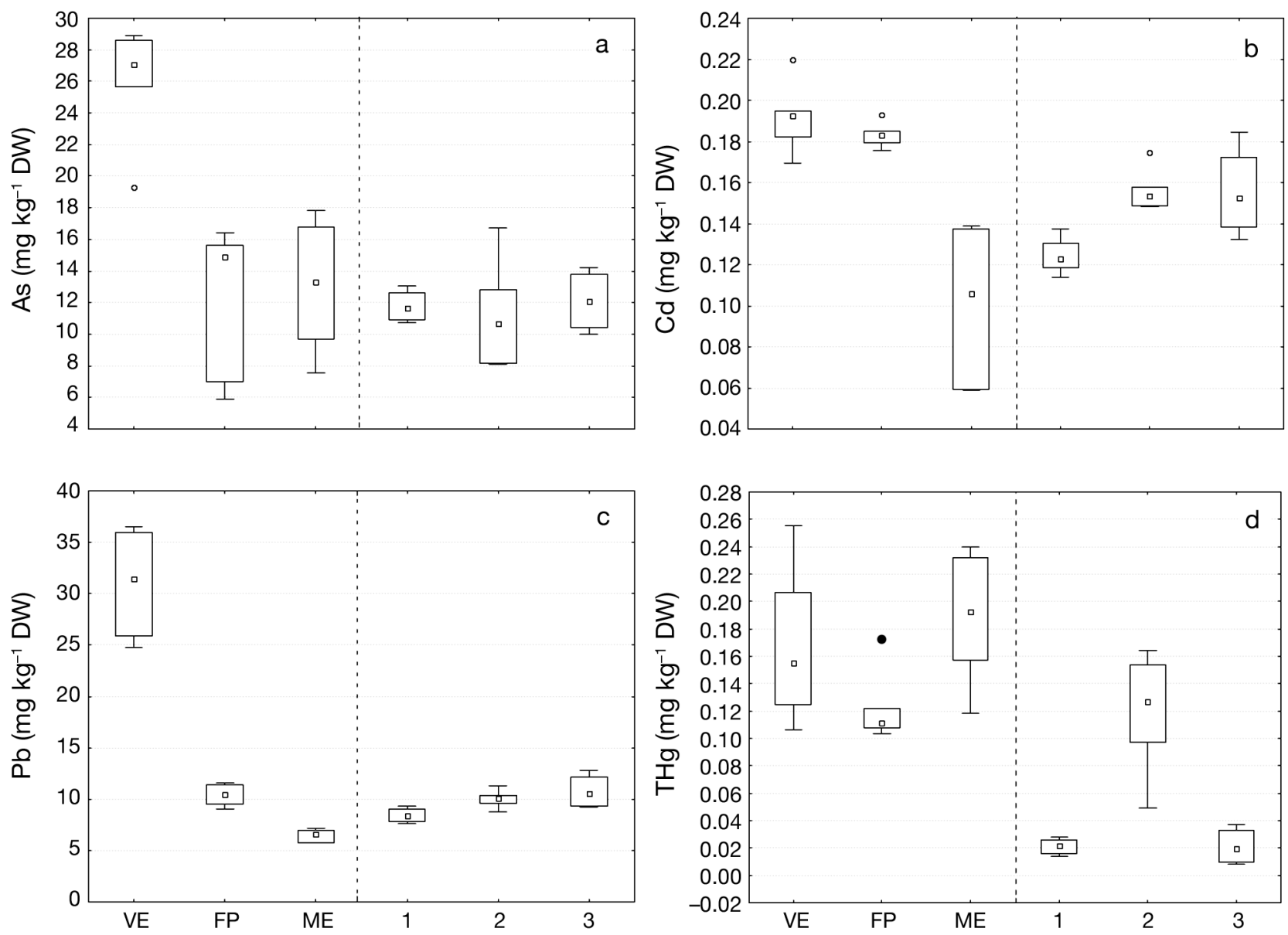

Fig. 2. Normalized trace metal concentrations per kg dry weight (DW) of surface sediments at the sampling sites: (a) arsenic, (b) cadmium, (c) lead, (d) total mercury. Pond sites: Verde (VE), Fondo Porto (FP), Mergolo (ME); coastal sites: 1, 2, 3. Whiskers indicate the non-outlier range of variation; boxes: 25th to 75th percentiles; squares inside boxes: median; O: outliers; $\bullet$ : extremes

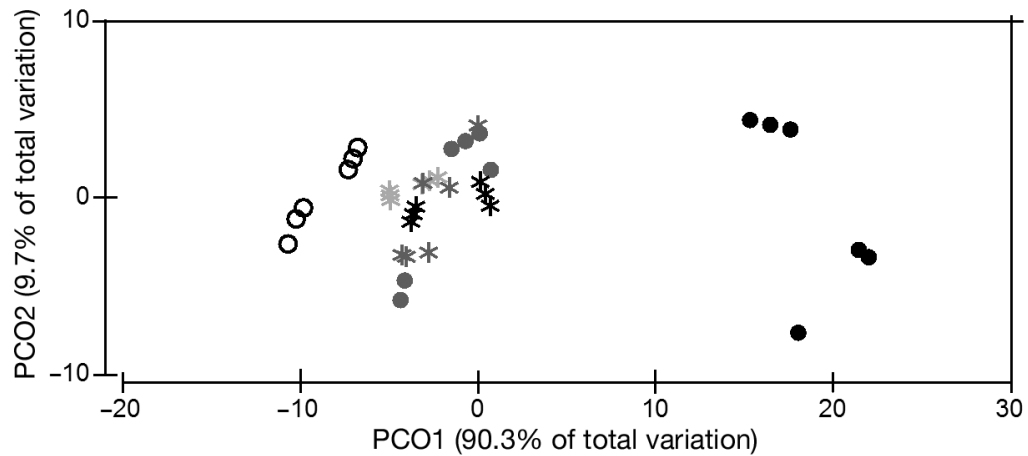

Fig. 3. Principal coordinates analysis (PCO) ordination based on normalized Euclidean distance of trace metal concentrations of surface sediments at the sampling sites. The contribution of each axis (PCO1 and PCO2) to the total variation is shown. Pond sites: Verde (๑), Fondo Porto (๑), Mergolo (0): coastal sites $1(*), 2(*)$ and $3(*)$

concentrations of biota in all ponds (Fig. 5). Slopes of the regressions were homogeneous among ponds for all trace metals (As: $F=2.29$; $\mathrm{Cd}: F=1.44 ; \mathrm{Pb}: F=$
1.81; THg: $F=0.59 ; \mathrm{p}>0.05)$, and were negative for $\mathrm{As}, \mathrm{Cd}$ and $\mathrm{Pb}$, and positive for THg.

\section{DISCUSSION}

\section{Trace metal contamination}

Sediments of coastal areas supply time-integrated information about ecosystem health as they represent the major storage compartment for trace metals, acting contextually as a sink and source (Eggleton \& Thomas 2004, Du Laing et al. 2009). The trace metal distribution pattern in the Marinello area revealed marked spatial variations independent of sediment characteristics. Of the 3 ponds, VE showed the high- 
Table 2. Trace metal concentrations (means $\pm \mathrm{SD}_{;} \mathrm{mg} \mathrm{kg}^{-1} \mathrm{dw}$ ) of (a) organic matter (OM) sources, (b) invertebrates and (c) fish from pond sites: Verde (VE), Fondo Porto (FP), Mergolo (ME). POM: particulate organic matter

\begin{tabular}{|c|c|c|c|c|c|c|}
\hline Item & Species/family & Pond & $\longrightarrow$ As - & $-\mathrm{Cd}-$ & $-\mathrm{Pb}=$ & $-\mathrm{THg}$ \\
\hline \multirow[t]{13}{*}{ (a) OM sources } & POM & VE & $5.42 \pm 1.26$ & $3.81 \pm 0.37$ & $9.64 \pm 2.32$ & $0.52 \pm 0.02$ \\
\hline & & FP & $4.62 \pm 0.87$ & $1.48 \pm 0.64$ & $7.27 \pm 2.86$ & $0.14 \pm 0.01$ \\
\hline & & ME & $2.66 \pm 0.53$ & $0.82 \pm 0.22$ & $2.63 \pm 0.49$ & $0.09 \pm 0.01$ \\
\hline & Caulerpa racemosa & FP & $1.47 \pm 0.27$ & $0.82 \pm 0.08$ & $1.08 \pm 0.05$ & $0.08 \pm 0.02$ \\
\hline & Chaetomorpha linum & VE & $15.00 \pm 0.34$ & $0.81 \pm 0.14$ & $0.78 \pm 0.14$ & $0.08 \pm 0.02$ \\
\hline & & FP & $1.64 \pm 0.50$ & $0.17 \pm 0.04$ & $1.08 \pm 0.56$ & $0.27 \pm 0.14$ \\
\hline & & ME & $2.12 \pm 0.54$ & $0.09 \pm 0.03$ & $0.88 \pm 0.17$ & $0.28 \pm 0.23$ \\
\hline & Cymodocea nodosa & VE & $4.39 \pm 0.92$ & $0.80 \pm 0.03$ & $1.87 \pm 0.84$ & $0.37 \pm 0.02$ \\
\hline & & FP & $4.87 \pm 0.47$ & $0.66 \pm 0.05$ & $0.57 \pm 0.14$ & $0.12 \pm 0.04$ \\
\hline & & ME & $1.63 \pm 0.09$ & $0.53 \pm 0.16$ & $0.23 \pm 0.17$ & $0.33 \pm 0.02$ \\
\hline & Ruppia cirrhosa & $\mathrm{VE}$ & $3.66 \pm 0.54$ & $0.46 \pm 0.21$ & $1.47 \pm 1.29$ & $0.19 \pm 0.15$ \\
\hline & & FP & $9.01 \pm 1.19$ & $0.59 \pm 0.19$ & $3.42 \pm 0.99$ & $0.13 \pm 0.01$ \\
\hline & & $\mathrm{ME}$ & $7.67 \pm 0.91$ & $0.17 \pm 0.09$ & $3.91 \pm 0.42$ & $0.28 \pm 0.15$ \\
\hline \multirow[t]{18}{*}{ (b) Invertebrates } & Cerastoderma glaucum & VE & $6.66 \pm 0.90$ & $0.49 \pm 0.23$ & $0.42 \pm 0.15$ & $0.66 \pm 0.12$ \\
\hline & & ME & $4.22 \pm 1.01$ & $0.40 \pm 0.08$ & $0.32 \pm 0.10$ & $0.72 \pm 0.06$ \\
\hline & Cerithium sp. & FP & $8.40 \pm 0.60$ & $3.71 \pm 1.10$ & $0.41 \pm 0.07$ & $0.19 \pm 0.04$ \\
\hline & & ME & $2.01 \pm 0.22$ & $1.55 \pm 0.31$ & $0.17 \pm 0.02$ & $0.47 \pm 0.00$ \\
\hline & Corophium sp. & VE & $4.73 \pm 1.15$ & $0.32 \pm 0.15$ & $0.12 \pm 0.05$ & $0.99 \pm 0.24$ \\
\hline & & $\mathrm{FP}$ & $6.16 \pm 1.67$ & $0.61 \pm 0.38$ & $0.25 \pm 0.13$ & $1.26 \pm 0.68$ \\
\hline & Hydrobia ventrosa & VE & $4.39 \pm 0.13$ & $0.17 \pm 0.01$ & $0.10 \pm 0.03$ & $0.74 \pm 0.03$ \\
\hline & & FP & $2.41 \pm 0.50$ & $0.14 \pm 0.02$ & $0.17 \pm 0.00$ & $0.52 \pm 0.02$ \\
\hline & & $\mathrm{ME}$ & $1.42 \pm 0.21$ & $0.12 \pm 0.04$ & $0.12 \pm 0.04$ & $0.57 \pm 0.05$ \\
\hline & Orbiniidae & $\mathrm{VE}$ & $4.71 \pm 0.24$ & $0.11 \pm 0.04$ & $0.11 \pm 0.02$ & $0.40 \pm 0.09$ \\
\hline & & $\mathrm{FP}$ & $6.48 \pm 0.50$ & $0.28 \pm 0.04$ & $0.05 \pm 0.02$ & $1.00 \pm 0.02$ \\
\hline & & ME & $6.51 \pm 0.56$ & $0.06 \pm 0.03$ & $0.05 \pm 0.02$ & $0.17 \pm 0.01$ \\
\hline & Palaemon adspersus & VE & $0.68 \pm 0.21$ & $0.13 \pm 0.05$ & $0.07 \pm 0.02$ & $0.71 \pm 0.23$ \\
\hline & & $\mathrm{FP}$ & $0.34 \pm 0.14$ & $0.25 \pm 0.08$ & $0.04 \pm 0.01$ & $0.62 \pm 0.21$ \\
\hline & & ME & $1.15 \pm 0.31$ & $0.14 \pm 0.02$ & $0.09 \pm 0.05$ & $0.80 \pm 0.28$ \\
\hline & Sphaeroma serratum & VE & $1.54 \pm 0.21$ & $0.27 \pm 0.05$ & $0.21 \pm 0.03$ & $1.73 \pm 0.26$ \\
\hline & & ME & $1.83 \pm 0.41$ & $0.20 \pm 0.01$ & $0.12 \pm 0.04$ & $1.18 \pm 0.23$ \\
\hline & Venerupis sp. & FP & $6.67 \pm 0.08$ & $1.39 \pm 0.18$ & $0.12 \pm 0.02$ & $0.90 \pm 0.05$ \\
\hline \multirow[t]{13}{*}{ (c) Fish } & Atherina boyeri & VE & $2.19 \pm 0.19$ & $0.23 \pm 0.03$ & $0.12 \pm 0.08$ & $2.07 \pm 0.18$ \\
\hline & & FP & $2.18 \pm 0.17$ & $0.04 \pm 0.01$ & $0.26 \pm 0.01$ & $2.67 \pm 0.30$ \\
\hline & & ME & $0.72 \pm 0.18$ & $0.11 \pm 0.01$ & $0.13 \pm 0.05$ & $1.75 \pm 0.33$ \\
\hline & Gambusia holbrooki & VE & $3.97 \pm 0.33$ & $0.30 \pm 0.08$ & $0.21 \pm 0.03$ & $2.22 \pm 0.45$ \\
\hline & & FP & $1.45 \pm 0.07$ & $0.14 \pm 0.03$ & $0.15 \pm 0.02$ & $1.91 \pm 0.35$ \\
\hline & & ME & $1.47 \pm 0.30$ & $0.01 \pm 0.01$ & $0.14 \pm 0.07$ & $1.41 \pm 0.63$ \\
\hline & Gobius niger & VE & $1.16 \pm 0.22$ & $0.03 \pm 0.00$ & $0.02 \pm 0.02$ & $0.60 \pm 0.25$ \\
\hline & & FP & $0.98 \pm 0.65$ & $0.02 \pm 0.02$ & $0.03 \pm 0.00$ & $0.57 \pm 0.17$ \\
\hline & Liza aurata & VE & $4.44 \pm 0.33$ & $0.45 \pm 0.08$ & $0.54 \pm 0.17$ & $0.70 \pm 0.05$ \\
\hline & & ME & $2.53 \pm 0.48$ & $0.28 \pm 0.02$ & $0.25 \pm 0.00$ & $4.12 \pm 0.56$ \\
\hline & Salaria pavo & $\mathrm{VE}$ & $0.34 \pm 0.08$ & $0.06 \pm 0.02$ & $0.13 \pm 0.02$ & $1.53 \pm 0.47$ \\
\hline & & FP & $0.70 \pm 0.09$ & $0.16 \pm 0.01$ & $0.15 \pm 0.01$ & $1.85 \pm 0.04$ \\
\hline & & ME & $0.36 \pm 0.10$ & $0.04 \pm 0.01$ & $0.10 \pm 0.01$ & $1.03 \pm 0.13$ \\
\hline
\end{tabular}

est concentrations of $\mathrm{As}, \mathrm{Cd}$ and $\mathrm{Pb}$, followed by FP and $\mathrm{ME}$, mirroring the increasing distance from the gull colony. Although THg levels were more comparable between ponds, a multivariate approach confirmed the trace metal pattern of the whole Marinello area, highlighting the marked difference between VE and the other sites. In spite of the almost pristine character of the Marinello area, which is far from urban centres and is characterised by very low anthropogenic impact, the As and THg values of VE were comparable with areas affected by higher human pressure (e.g. Venice lagoon, Bellucci et al. 2002; southern French lagoons, Accornero et al. 2008). Further, $\mathrm{As}, \mathrm{THg}$ and $\mathrm{Pb}$ sediment content 

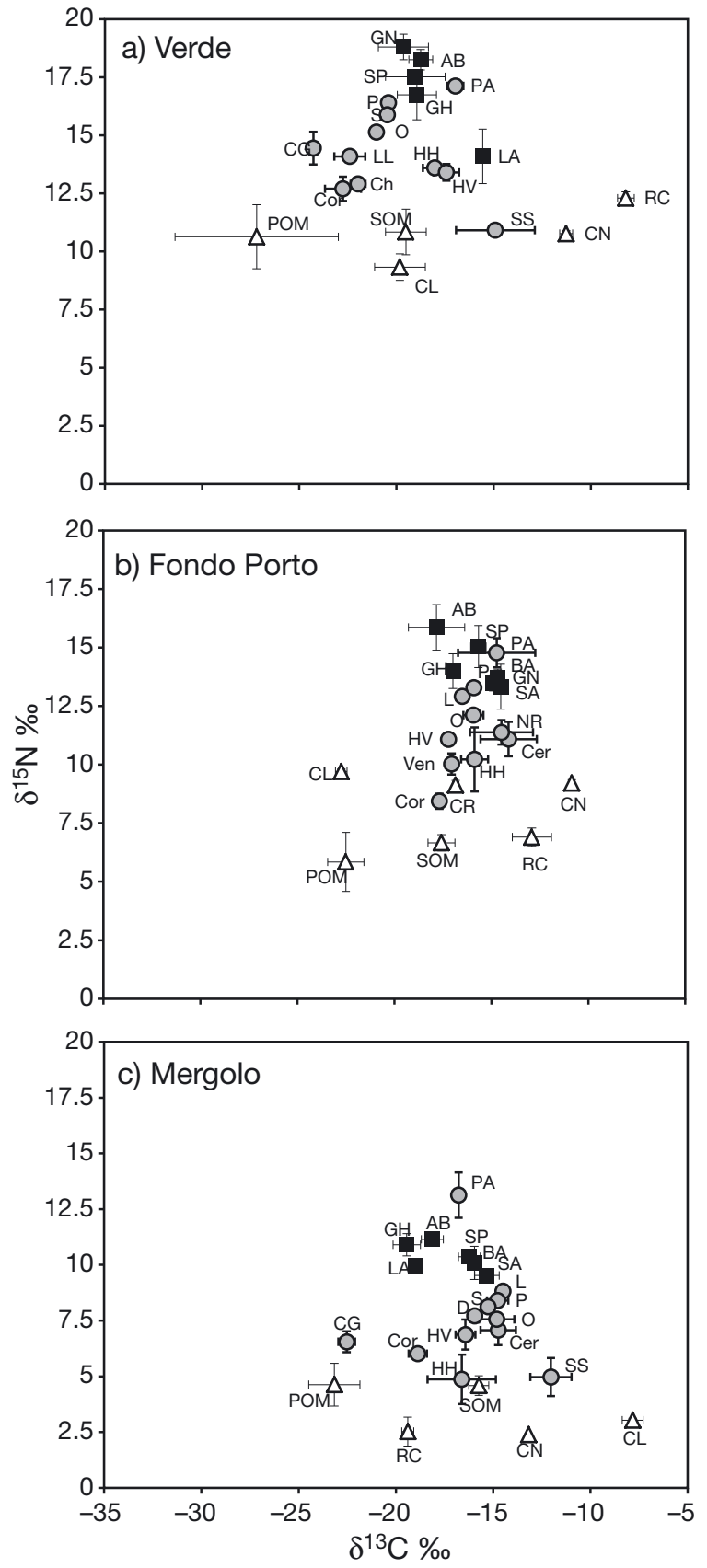

Fig. 4. $\delta^{13} \mathrm{C}$ vs. $\delta^{15} \mathrm{~N}$ (means $\pm \mathrm{SD}$ ) of organic matter sources $(\triangle)$, invertebrates $(O)$ and fish $(\square)$ from the Marinello ponds: (a) Verde, (b) Fondo Porto, (c) Mergolo. SOM: sedimentary organic matter; POM: particulate organic matter. Macroalgae, CL: Chaetomorpha linum, CR: Caulerpa racemosa. Seagrasses, CN: Cymodocea nodosa, RC: Ruppia cirrhosa. Invertebrates, CG: Cerastoderma glaucum, Ch: Chironomidae (larvae), Cor: Corophium sp., Cer: Cerithium sp., D: Dorvilleidae, HH: Haminoea hydatis, HV: Hydrobia ventrosa, L: Lumbrineridae, NR: Nassarius reticulatus, O: Orbiniidae, PA: Palaemon adspersus, P: Paraonidae, SS: Sphaeroma serratum, S: Syllidae, Ven: Venerupis sp. Fish, AB: Atherina boyeri, BA: Buenia affinis, GH: Gambusia holbrooki, GN: Gobius niger, LA: Liza aurata, SP: Salaria pavo, SA: Syngnathus abaster were higher than those of Canadian Arctic areas affected by conspicuous bird colonies (Brimble et al. 2009, Michelutti et al. 2010). Trace metal concentrations in the marine sediments also showed spatial variations, with a tendency to increase from upstream to downstream and a significant peak in the site adjacent to VE and FP, which was especially marked for THg. Thus, while prevailing currents in the littoral area are responsible for the increasing trend along the SE direction, the peak in the site adjacent to the ponds supports their influence on the marine area excluding the hypothesis of a possible influence of the marine area on pond contamination.

Differences in trace metal contamination between VE and the surrounding area were previously observed by Ruta et al. (2009), but the present research recognizes that guano represents an important allochthonous input of trace metals in VE. Seabird droppings have indeed been acknowledged to be a significant source of trace metals in polar (Godzik 1991, Blais et al. 2005, Brimble et al. 2009) and temperate areas (e.g. the Spanish coasts: Otero Pérez 1998) at high bird densities. Seabirds are exposed to pollutants mainly through inhalation, ingestion or dermal exposure (Burger \& Gochfeld 2004), and seabird guano contains trace metals derived mainly from the diet accumulated in the organs, to be excreted through various physiological pathways (Burger \& Gochfeld 2004). This is expected to occur especially in gulls because of their opportunistic feeding behaviour, with much of their diet made up of municipal rubbish (Ramos et al. 2009).

\section{Trophic pathways}

Considering the commonly recognized trophic fractionation $\left(\delta^{13} \mathrm{C}=0-1 \%\right.$; $\delta^{15} \mathrm{~N}=3-4 \%$; De Niro \& Epstein 1978, Minagawa \& Wada 1984, Post 2002) occurring between a consumer and its diet, a different role of OM sources for consumers is apparent in the Marinello ponds. Distinct trophic pathways are indeed evident: an important phytoplanktonic pathway (based on POM) clearly dominates in VE, while a phytobenthic pathway (based on SOM and benthic primary producers) prevails in FP and ME (Fig. 4). In more detail, in VE, POM seems to contribute directly to the diet of filter-suspension feeding bivalves (Cerastoderma glaucum and Loripes lacteus) and suspension-deposit feeders (chironomid larvae and Corophium sp.), while among secondary consumers, an indirect contribution from POM appears evident for polychaetes, 

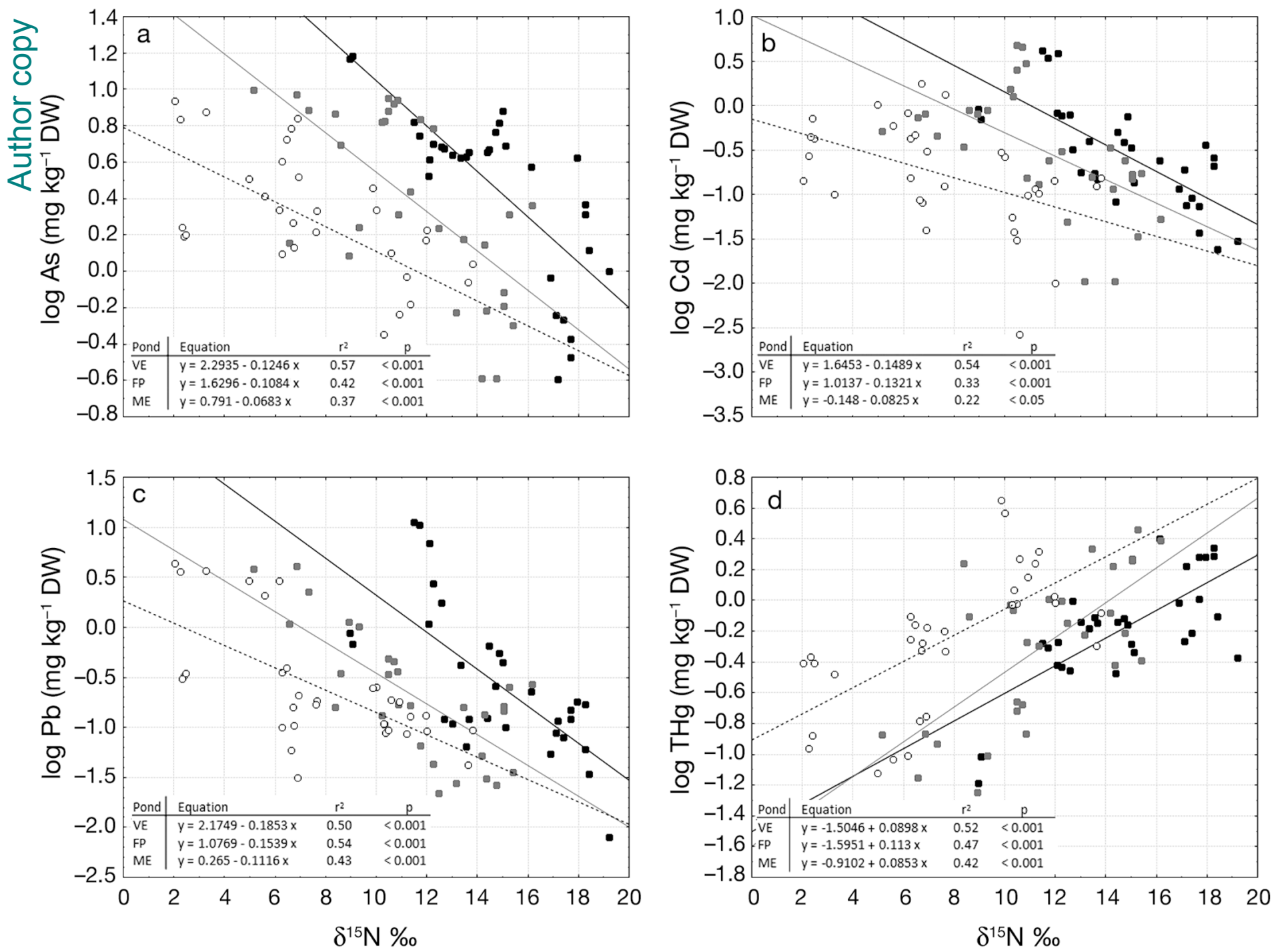

Fig. 5. Linear regressions between $\delta^{15} \mathrm{~N}$ values and log-transformed trace metal concentrations (mg kg $\left.{ }^{-1} \mathrm{DW}\right)$ : (a) arsenic, (b) cadmium, (c) lead, (d) total mercury in organic matter sources, invertebrates and fish from the Marinello ponds: Verde

$(\mathrm{VE},-)$ Fondo Porto (FP, - ) and Mergolo (ME, O)

most fish and the prawn Palaemon adspersus, all of which are carnivores-omnivores-invertebrate feeders (Fauchauld \& Jumars 1979, Vizzini et al. 2002). A secondary phytobenthic trophic pathway, based mainly on SOM and Chaetomorpha linum, seems to be less important, supporting only a few consumers (Haminoea hydatis, Hydrobia ventrosa and Liza aurata), while Ruppia cirrhosa and Sphaeroma serratum did not seem to be part of any of the observed pathways.

Unlike in VE, consumers in FP seem to depend, directly or indirectly, on only 1 trophic pathway, originating mainly from SOM and the seagrass Ruppia cirrhosa, while POM, Chaetomorpha linum and $\mathrm{Cy}$ modocea nodosa do not appear to be important OM sources for consumers. The trophic structure of the third pond, ME, showed the coexistence of 2 distinct trophic pathways: a phytoplanktonic pathway originating from POM seems to directly involve the bivalve filter feeder Cerastoderma glaucum and, indirectly, a number of fish (Atherina boyeri, Gambusia holbrooki and Liza aurata). A phytobenthic pathway, originating instead from SOM and the seagrasses, seems to directly affect most of the invertebrates, filter-deposit-suspension feeders, and indirectly carnivorous-omnivorous polychaetes and the other fish. The generalist predator Palaemon adspersus seems to rely indirectly on both the trophic pathways identified, while the macroalga $C$. linum does not seem to be part of any of the observed pathways. 


\section{Trace metal trophic transfer to the biota}

Primary producers from the Marinello coastal ponds exhibited a decreasing trace metal concentrations with increasing distance from the Tindari cliff gull colony, as discussed above with relation to surface sediment. The scarcity of similar studies makes inferences difficult; however, Godzik (1991), Grodzinska \& Godzik (1991) and, more recently, Liu et al. (2006) found trace metal content in mosses and terrestrial plants from seabird-impacted areas to be higher than those from non-impacted areas, due to guano deposition. Similar to the ambiguous spatial trend of $\mathrm{THg}$ in surface sediment, $\mathrm{THg}$ in primary producers did not follow the trend of the other trace metals, as observed in Cape Vera (Devon Island, Canada), where distance from a seabird colony did not affect THg concentration in surrounding primary producers (Choy et al. 2010a). The high variability in trace metal content of OM sources is due to the complex and variable accumulation patterns of the different species. Indeed, various factors influence their metal uptake, e.g. morphology and species-specific trace metal affinity (e.g. Sawidis et al. 2001, Llagostera et al. 2011). Unlike in OM sources, trace metal concentrations of invertebrates and fish did not show any clear spatial pattern. Trace metal accumulation in biota appears to be highly variable in relation to several biotic and abiotic factors: metal species (Luoma \& Rainbow 2005), trophic level or guild (Barwick \& Maher 2003), size, season and sex (Al-Yousuf et al. 2000, Yilmaz \& Yilmaz 2007). The detoxification capacity of a species in relation to different trace metals is also highly variable (Amiard et al. 2006).

With regard to the trophic transfer of ornithogenic elements, very few studies have been carried out, and these have dealt almost exclusively with the transfer of nitrogen and POPs, PCBs and DDT into terrestrial food chains (Harding et al. 2004, Choy et al. 2010b, Kolb et al. 2010). As for ornithogenic trace metal biomagnification along food chains, the only inherent study did not detect biomagnification of ornithogenic THg in an Arctic terrestrial food web (Choy et al. 2010a). In contrast, the highly significant correlation between $\delta^{15} \mathrm{~N}$ and $\log \mathrm{THg}$ concentration and the positive slope of the linear regressions obtained in our study showed that THg biomagnified. As the slopes of the linear regression between $\delta^{15} \mathrm{~N}$ and $\log \mathrm{THg}$ concentration in samples from the 3 ponds were homogeneous, the THg biomagnification power was comparable among ponds. Methylmercury (MeHg, not analysed here), is considered to be the most responsible $\mathrm{Hg}$ form for both bioaccumu- lation and biomagnification (Furness \& Camphuysen 1997, Gochfeld 2003). Methylation is carried out by sulphur-reducing anaerobic bacteria in fine sediments and is favoured by biotic and abiotic features (i.e. low $\mathrm{pH}$ and $\mathrm{Eh}$, high temperature, sulphate and OM content; Sunderland et al. 2006) that are frequent in transitional areas. The lower THg concentration in pond sediment, compared to the higher concentration in guano and the biota, may be explained by the intense methylation process of the sedimentary $\mathrm{Hg}$ pool, which results in higher bioavailability for the biota.

In contrast, $\mathrm{As}, \mathrm{Cd}$ and $\mathrm{Pb}$ showed a significant biodilution. The relatively elevated concentrations of these trace metals in POM and macrophytes reveal the high availability of these metal ions and high uptake rates in primary producers. Gray (2002) stated that only mercury (as MeHg) truly biomagnifies along food chains, while most of the other metals do not, due to the regulation and excretion capacities of biota during the trophic transfer process. Many studies on aquatic systems confirm this statement, observing clear biodilution of both $\mathrm{Cd}$ and $\mathrm{Pb}$ (Barwick \& Maher 2003, Campbell et al. 2005, Nfon et al. 2009). While it is widely recognized that $\mathrm{Pb}$ does not biomagnify, some cases of $\mathrm{Cd}$ biomagnification have been described in both marine (Cheung \& Wang 2008) and freshwater systems (Croteau et al. 2005). The situation for As is more controversial, as biodilution has been observed in freshwater food chains (Chen \& Folt 2000), and biomagnification in an estuarine food chain (Barwick \& Maher 2003), while several other studies identified no clear significant trend for As along trophic levels (Campbell et al. 2005, Nfon et al. 2009).

In the Mediterranean coastal area of the Marinello ponds, bioaccumulation of trace metals in primary producers was related to the degree of avian input. Further, for the first time we have shown that ornithogenic trace metal biomagnification takes place, but only for THg. Indeed, trophic transfer of trace metals was metal-specific and independent of the differences in background contamination.

\section{CONCLUSIONS}

Non-essential trace metals in coastal systems are an environmental and human health concern. Seabird-mediated transport provides not only an intense nutrient subsidy triggering guanotrophication in aquatic systems, but contextually, seabirds can channel anthropogenic non-essential trace metals to 
remote areas. Enhanced nutrient levels and concomitant exchange of contaminants in coastal lagoons are phenomena which are not yet well characterised. While the former phenomenon was previously demonstrated in the Mediterranean coastal area of the Marinello ponds (Signa et al. 2012), we now provided evidence of the latter, demonstrating that even small gull colonies can represent an important trace metal source in coastal ecosystems. Considering the high abundance of seabirds in Mediterranean coastal areas and the lack of knowledge about birdmediated processes, these results could aid in the interpretation of ecological processes in transitional areas.

Acknowledgements. We thank A. Savona for assistance during field work, V. Costa for help with biota identification and statistical support and E. A. Aleo for stable isotope analysis. Many thanks to Director M. L. Molino and the staff of the Nature Reserve 'Laghetti di Marinello' for permission to work in the reserve and for the support provided. Our study was funded by the University of Palermo. This manuscript was awarded the first edition (2012) of the research prize 'Francesco Maria Faranda' in honour of the founder of CoNISMa, the National Interuniversity Consortium for Marine Sciences (Roma-Italia).

\section{LITERATURE CITED}

Accornero A, Gnerre R, Manfra L (2008) Sediment concentrations of trace metals in the Berre lagoon (France): an assessment of contamination. Arch Environ Contam Toxicol 54:372-385

Acquavita A, Covelli S, Emili A, Berto D and others (2012) Mercury in the sediments of the Marano and Grado Lagoon (northern Adriatic Sea): sources, distribution and speciation. Estuar Coast Shelf Sci 113:20-31

> Al-Yousuf MH, El-Shahawi MS, Al-Ghais SM (2000) Trace metals in liver, skin and muscle of Lethrinus lentjan fish species in relation to body length and sex. Sci Total Environ 256:87-94

> Amiard JC, Amiard-Triquet C, Barka S, Pellerin J, Rainbow PS (2006) Metallothioneins in aquatic invertebrates: their role in metal detoxification and their use as biomarkers. Aquat Toxicol 76:160-202

Barwick M, Maher W (2003) Biotransference and biomagnification of selenium copper, cadmium, zinc, arsenic and lead in a temperate seagrass ecosystem from Lake Macquarie Estuary, NSW, Australia. Mar Environ Res 56: 471-502

> Bellucci LG, Frignani M, Paolucci D, Ravanelli M, Giorgio L (2002) Distribution of heavy metals in sediments of the Venice Lagoon: the role of the industrial area. Sci Total Environ 295:35-49

Blais JM, Kimpe LE, McMahon D, Keatley BE, Mattory ML, Douglas MSV, Smol JP (2005) Arctic seabirds transport marine-derived contaminants. Science 309:445

Boubonari T, Kevrekidis T, Malea P (2009) Metal (Fe, Zn, $\mathrm{Cu}, \mathrm{Pb}$ and $\mathrm{Cd}$ ) concentration patterns in components of a macrophyte-based coastal lagoon ecosystem. Hydro- biologia 635:27-36

Brimble SK, Foster KL, Mallory ML, MacDonald RW, Smol JP, Blais JM (2009) High arctic ponds receiving biotransported nutrients from a nearby seabird colony are also subject to potentially toxic loadings of arsenic, cadmium, and zinc. Environ Toxicol Chem 28:2426-2433

- Burger J, Gochfeld M (2004) Marine birds as sentinels of environmental pollution. EcoHealth 1:263-274

> Campbell LM, Norstrom RJ, Hobson KA, Muir DC, Backus S, Fisk AT (2005) Mercury and other trace elements in a pelagic Arctic marine food web (Northwater Polynya, Baffin Bay). Sci Total Environ 351-352:247-263

Carlier A, Riera P, Amouroux JM, Bodiou JY, Desmalades M, Grémare A (2009) Spatial heterogeneity in the food web of a heavily modified Mediterranean coastal lagoon: stable isotope evidence. Aquat Biol 5:167-179

> Chen CY, Folt CL (2000) Bioaccumulation and diminution of arsenic and lead in a freshwater food web. Environ Sci Technol 34:3878-3884

> Cheung MS, Wang WX (2008) Analyzing biomagnification of metals in different marine food webs using nitrogen isotopes. Mar Pollut Bull 56:2082-2088

Choy ES, Gauthier M, Mallory ML, Smol JP, Douglas MSV, Lean D, Blais JM (2010a) An isotopic investigation of mercury accumulation in terrestrial food webs adjacent to an Arctic seabird colony. Sci Total Environ 408: 1858-1867

Choy ES, Kimpe LE, Mallory ML, Smol JP, Blais JM (2010b) Contamination of an arctic terrestrial food web with marine-derived persistent organic pollutants transported by breeding seabirds. Environ Pollut 158:3431-3438

> Corsolini S, Sarà G, Borghesi N, Focardi S (2007) HCB p,p'$\mathrm{DDE}$ and $\mathrm{PCB}$ ontogenetic transfer and magnification in bluefin tuna (Thunnus thynnus) from the Mediterranean Sea. Environ Sci Technol 41:4227-4233

Croteau MN, Luoma SN, Stewart RA (2005) Trophic transfer of metals along freshwater food webs: evidence of cadmium biomagnification in nature. Limnol Oceanogr 50: 1511-1519

> De Niro MJ, Epstein S (1978) Influence of diet on the distribution of carbon isotopes in animals. Geochim Cosmochim Acta 42:495-506

> Du Laing G, Rinklebe J, Vandecasteele B, Meers E, Tack FMG, Laing GD (2009) Trace metal behaviour in estuarine and riverine floodplain soils and sediments: a review. Sci Total Environ 407:3972-3985

Eggleton J, Thomas KV (2004) A review of factors affecting the release and bioavailability of contaminants during sediment disturbance events. Environ Int 30:973-980

Fauchauld K, Jumars PA (1979) The diet of worms: a study of polychaete feeding guilds. Oceanogr Mar Biol Annu Rev 17:193-284

- Furness RW, Camphuysen K (1997) Seabirds as monitors of the marine environment. ICES J Mar Sci 54:726-737

> Gochfeld M (2003) Cases of mercury exposure, bioavailability, and absorption. Ecotoxicol Environ Saf 56:174-179

Godzik B (1991) Heavy metals and macroelements in the tundra of southern Spitsbergen: the effect of little auk Alle alle (L.) colonies. Polar Res 9:121-131

Gray JS (2002) Biomagnification in marine systems: the perspective of an ecologist. Mar Pollut Bull 45:46-52

Green-Ruiz C, Páez-Osuna F (2001) Heavy metal anomalies in lagoon sediments related to intensive agriculture in Altata-Ensenada del Pabellòn coastal system (SE Gulf of California). Environ Int 26:265-273 
Grodzinska K, Godzik B (1991) Heavy metals and sulphur in mosses from southern Spitsbergen. Polar Res 9: 133-140

Hahn S, Bauer S, Klaassen M (2007) Estimating the contribution of carnivorous waterbirds to nutrient loading in freshwater habitats. Freshw Biol 52:2421-2433

Harding JS, Hawke DJ, Holdaway RN, Winterbourn MJ (2004) Incorporation of marine-derived nutrients from petrel breeding colonies into stream food webs. Freshw Biol 49:576-586

Heiri O, Lotter AF, Lemcke G (2001) Loss on ignition as a method for estimating organic and carbonate content in sediments: reproducibility and comparability of results. J Paleolimnol 25:101-110

Horowitz AJ (1985) A primer on trace metal-sediment chemistry. Water-Supply Paper 2227. United States Geological Survey, Alexandria, VA

Ikemoto T, Tu NPC, Okuda N, Iwata A and others (2008) Biomagnification of trace elements in the aquatic food web in the Mekong Delta, South Vietnam using stable carbon and nitrogen isotope analysis. Arch Environ Contam Toxicol 54:504-515

Knee KL, Paytan A (2011) Submarine groundwater discharge: a source of nutrients, metals, and pollutants to the coastal ocean. In: Wolanski E, McLusky D (eds) Treatise on estuarine and coastal science. Academic Press, Waltham, MA, p 205-234

Kolb GS, Ekholm J, Hambäck PA (2010) Effects of seabird nesting colonies on algae and aquatic invertebrates in coastal waters. Mar Ecol Prog Ser 417:287-300

Liu XD, Zhao SP, Sun LG, Yin XB, Xie ZQ, Honghao L, Wang YH (2006) P and trace metal contents in biomaterials, soils, sediments and plants in colony of red-footed booby (Sula sula) in the Dongdao Island of South China Sea. Chemosphere 65:707-715

Llagostera I, Pérez M, Romero J (2011) Trace metal content in the seagrass Cymodocea nodosa: differential accumulation in plant organs. Aquat Bot 95:124-128

Luoma SN, Rainbow PS (2005) Why is metal bioaccumulation so variable? Biodynamics as a unifying concept. Environ Sci Technol 39:1921-1931

Magni P, Rajagopal S, van der Velde G, Fenzi G and others (2008) Sediment features, macrozoobenthic assemblages and trophic relationships $\left(\delta^{13} \mathrm{C}\right.$ and $\delta^{15} \mathrm{~N}$ analysis) following a dystrophic event with anoxia and sulphide development in the Santa Giusta lagoon (western Sardinia, Italy). Mar Pollut Bull 57:125-136

Marín-Guirao L, Atucha AM, Barba JL, López EM, Fernández AJ (2005) Effects of mining wastes on a seagrass ecosystem: metal accumulation and bioavailability, seagrass dynamics and associated community structure. Mar Environ Res 60:317-337

Marín-Guirao L, Lloret J, Marin A (2008) Carbon and nitrogen stable isotopes and metal concentration in food webs from a mining-impacted coastal lagoon. Sci Total Environ 393:118-130

Mazzola A, Bergamasco A, Calvo S, Caruso G and others (2010) Sicilian transitional waters: current status and future development. Chem Ecol 26:267-283

Editorial responsibility: Omar Defeo,

Montevideo, Uruguay
Michelutti N, Blais JM, Mallory ML, Brash J and others (2010) Trophic position influences the efficacy of seabirds as metal biovectors. Proc Natl Acad Sci USA 107: 10543-10548

Migon C, Morelli J, Nicolas E, Copin-Montegut G (1991) Evaluation of total atmospheric deposition of $\mathrm{Pb}, \mathrm{Cd}, \mathrm{Cu}$ and $\mathrm{Zn}$ to the Ligurian Sea. Sci Total Environ 105: $135-148$

Millot C (1999) Circulation in the western Mediterranean Sea. J Mar Syst 20:423-442

Minagawa M, Wada E (1984) Stepwise enrichment of ${ }^{15} \mathrm{~N}$ along food chains: further evidence and the relation between $\delta^{15} \mathrm{~N}$ and animal age. Geochim Cosmochim Acta 48:1135-1140

> Nfon E, Cousins IT, Järvinen O, Mukherjee AB, Verta M, Broman D (2009) Trophodynamics of mercury and other trace elements in a pelagic food chain from the Baltic Sea. Sci Total Environ 407:6267-6274

Otero Pérez XL (1998) Effects of nesting yellow-legged gulls (Larus cachinnans Pallas) on the heavy metal content of soils in the Cies Islands (Galicia, North-west Spain). Mar Pollut Bull 36:267-272

> Post DM (2002) Using stable isotopes to estimate trophic position: models, methods, and assumptions. Ecology 83 : 703-718

> Ramos R, Ramirez F, Sanpera C, Jover L, Ruiz X (2009) Diet of yellow-legged gull (Larus michahellis) chicks along the Spanish western Mediterranean coast: the relevance of refuse dumps. J Ornithol 150:265-272

> Ruta M, Pepi M, Franchi E, Renzi M and others (2009) Contamination levels and state assessment in the lakes of the Oliveri-Tindari Lagoon (North-Eastern Sicily, Italy). Chem Ecol 25:27-38

Sawidis T, Brown M, Zachariadis G, Sratis I (2001) Trace metal concentrations in marine macroalgae from different biotopes in the Aegean Sea. Environ Int 27:43-47

Signa G, Mazzola A, Vizzini S (2012) Effects of a small seagull colony on trophic status and primary production in a Mediterranean coastal system (Marinello ponds, Italy). Estuar Coast Shelf Sci 111:27-34

> Sunderland EM, Gobas FAPC, Branfireun BA, Heyes A (2006) Environmental controls on the speciation and distribution of mercury in coastal sediments. Mar Chem 102:111-123

Turner A (2002) Suspended particles: their role in estuarine biogeochemical cycles. Estuar Coast Shelf Sci 55: 857-883

Underwood AJ (1997) Experiments in ecology: their logical design and interpretation using analysis of variances. Cambridge University Press, Cambridge

Vizzini S, Sarà G, Michener RH, Mazzola A (2002) The trophic role of the macrophyte Cymodocea nodosa (Ucria) Asch. in a Mediterranean saltworks: evidence from carbon and nitrogen stable isotope ratios. Bull Mar Sci 71:1369-1378

Yilmaz AB, Yilmaz L (2007) Influences of sex and seasons on levels of heavy metals in tissues of green tiger shrimp (Penaeus semisulcatus de Hann, 1844). Food Chem 101: 1664-1669

Submitted: July 18, 2012; Accepted: November 30, 2012 Proofs received from author(s): March 25, 2013 